\title{
LETTERS
}

\section{Zopiclone overdose and flumazenil rescue}

An and Goodwin appropriately detail the use of flumazenil in select circumstances of benzodiazepine overdosing. ${ }^{1}$ As also suggested, most patients with benzodiazepine overdose recover after supportive therapy and without the need of pharmacological intervention. $Z$ drugs (including zopiclone) share gamma-aminobutyric acid (GABA) receptors more or less with the benzodiazepines. ${ }^{2}$ Along the same lines, zopiclone overdose has been effectively treated with flumazenil, although again most such overuses can be treated with supportive therapy only. ${ }^{2,3}$ It would be prudent then to share the same precautions for using flumazenil in zopiclone overdosing as it would be for the benzodiazepines.

\section{Nevio Cimolai MD}

Professor, Department of Pathology and Laboratory Medicine, Faculty of Medicine, University of British Columbia, Vancouver, BC

Cite as: CMAJ 2017 April 24;189:E613. doi: $10.1503 /$ cmaj.732933

\section{References}

1. An H, Goodwin J. Flumazenil in benzodiazepine overdose. CMAJ 2016;188:E537.

2. Cimolai N. Zopiclone: is it a pharmacologic agent for abuse? Can Fam Physician 2007;53:2124-9.

3. Cimolai N. Safety with zopiclone use: contemporary issues. Curr Psychopharmacol. In press.

Competing interests: None declared. 